Palæo-asiatic tribes of Siberia and the Indian tribes of the north-west coast of America, for which the strongest evidence lies in their mythologies.

As to the place and cultural stage at which the Thule culture originated, indications, at present far from definite, point to a period late in the Birnirk cultural stage, which itself must be regarded as an outgrowth of the Old Bering Sea culture, but with an even closer relationship to Punuk. Sites intermediate between Birnirk and the oldest eastern Thule sites excavated by Matthiassen are much desired.

The weight of evidence is against the Aleutian Islands having served as a migration route from Asia to America. The known cultural remains of the Aleutians are of an essentially Eskimoid or American character, showing that the islands must have been peopled from the Alaskan mainland. It would have been no difficult undertaking for such expert navigators as the early Aleuts to push on to the Com. mander Islands and Kamchatka, while the reverse journey is improbable for Asiatics. The character of the American (Alaskan and North-West) affinities in Kamchadal and Koryak culture and mythology favour the southern route from America to Asia over the Aleutian chain.

Although on theoretical grounds we are forced to assume that man originally entered the American continent at Bering Strait, archæological work in this region has as yet revealed no trace of these earliest immigrants ; nor has any trace of pre-Eskimo culture been found on St. Lawrence Island. It has, however, been shown that the Old Bering Sea culture of St. Lawrence Island is basic to existing phases of northern Eskimo culture from Siberia to Greenland. The bearing of the Alaskan investigations on the theory of a central origin of Eskimo culture is to show that the view put forward by Kaj Birket Smith of Caribou Eskimo culture as a form of proto-Eskimo is untenable, demanding as it does that this culture should have been static through a period of hundreds, or even thousands, of years, while everywhere else Eskimo culture was undergoing marked changes.

The existence of a number of elements in the Old Bering Sea culture, such as toggle-harpoons, sledges, kayak, etc., which are of widespread distribution in the Old World, but in the New World are found only among the Eskimo, points to an Old World origin for a culture which embodied the general features of Eskimo culture as we know it in its earliest western form; while certain indications suggest north-east Siberia, between the mouths of the Anadyr and Kolyma Rivers, as the area in which the Old Bering Sea culture in its specific form came into being.

\title{
Stimulation of Adventitious Root Formation by Chemicals
}

$\mathrm{O}^{\mathrm{N}}$ November 6, 1937, by invitation of the Director, a meeting to discuss the use of chemicals for stimulating the formation of roots on cuttings was held at the Royal Botanic Gardens, Kew. It is well known to botanists that, following the investigations on the Continent which led to the discovery, isolation and chemical identification of hormone-like substances controlling the growth of seedlings, these were found also to be capable of inducing the formation of adventitious roots. Since then, use has been made of $\beta$-indole-acetic acid and other synthetically produced substances in the hope that their application in aqueous solutions either directly in jars or by watering the compost would induce the formation of roots on cuttings. It would be of great value to horticulturists if cuttings of plants which do not 'strike' easily could be stimulated to do so in this way, or if the rooting of moderately easy subjects which are cultivated on a very large scale could be accelerated.

It is evident that an authoritative opinion concerning the practical value of these substances can be formed only as a result of co-operation between botanists, practical horticulturists and those who manufacture the chemicals. For this reason, those interested in the subject from these points of view were invited to the meeting at Kew. That interest in the subject is widespread may be judged from the ready response which was received to the invitation.

An unfortunate fact is that those plants which present most difficulty to experienced cultivators are in most instances precisely those which show least response to the application of chemicals that induce root formation. The degree of response exhibited by other plants appears to be more or less proportional to the ease with which they root without special treatment, the easiest subjects reacting with greater facility than the more difficult ones. So far as can be judged at present, the greatest hope for the practical utility of root-promoting substances will be in accelerating the rooting of woody cuttings of plants of 'medium' difficulty, as well as cuttings of herbaceous plants such as chrysanthemums which, although easy to propagate without special treatment, are cultivated on a very large scale. The production of a root system at the earliest possible moment is of great importance to nurserymen, especially with the latter type of material.

It will be appreciated that in the present state of knowledge the use of these substances is far from being a panacea for all propagating difficulties. Nearly everyone who spoke stressed the fact that the amount of experimental work which has hitherto been carried out on the practical application of these substances is too small to permit judgment on them to be passed. The fundamental physiological processes on which their activity depends are not at present understood at all. It has been known for many years that very dilute acetic acid possesses root-promoting properties, and its use has often been recommended to horticulturists. A point which needs elucidation is whether in fact the more complex root-promoting substances which have now come into prominence are superior to acetic acid. The small amount of experimental work to test this point which has so far been carried out rather indicates that they are, but the matter is by no means clear.

In view of the economic importance of the subject and the very varied experience necessary for assessing the value of various researches which are being or may be carried out on this subject in the future, a 
small committee of scientific workers and horticulturists is being set up, with headquarters at Kew, to discuss the practical value of the results obtained. It is hoped that the committee may serve as a medium for the exchange of ideas, and also as a body which may be consulted by those who are working at isolated centres and are not in a position to decide in what directions their researches might most usefully be carried out. If at any time it is felt that further open meetings could usefully be held, the committee will decide where and when these might take place.

\section{University Events}

Cambridge.-The title of Stokes lecturer in mathematics has been conferred on Dr. S. Goldstein.

The Vice-Chancellor gives notice that the Cavendish professorship of experimental physics is vacant by the death of Lord Rutherford. A meeting of the electors will be held on February 11. If a proposal which is at present before the University is approved, the stipend of the professor will be $£ 1,400$ a year or while the professor holds a fellowship of a College with dividend $£ 1,200$, in addition to a non-pensionable payment of $£ 200$ a year for administration. Candidates for the professorship are requested to communicate with the Vice-Chancellor, and to send him on or before February 1 ten copies of any statement or testimonial which they desire to submit to the electors. If testimonials and references are sent they should not, taken together, exceed four in number.

The Adam Smith Prize is awarded to S. R. Dennison of Trinity College.

OXFoRD.-S. J. Wright, for some years assistantdirector and recently acting-director of the Institute for Research in Agricultural Engineering, has been appointed director.

Dr. J. R. Raeburn has been appointed a research officer under the Committee for Rural Economy.

A. G. Ogston has been elected to a fellowship at Balliol College for work in the biological sciences.

Dr. A. G. Gibson, Nuffield reader in morbid anatomy, has been elected to a professorial fellowship at Merton College.

Viscount Cecil of Chelwood has been appointed Romanes Lecturer for 1938.

The numbers of those reading the various main subjects of study in the academic year 1936-37 have recently been compiled. The largest science 'schools' are chemistry (207), physiology (194) and mathematics (143). Then come the new school of geography (100), agriculture and forestry (76), physics (59), zoology (40), engineering, botany and geology. About nine per cent of those reading these subjects are women. These numbers are greater than the corresponding numbers of the last survey. They are still small, however, compared with those of many other subjects. History (931), 'Greats', philosophy, politics and economics, and modern languages have each more than twice as many students as chemistry. Then come, in descending order of numbers, law (405), English, theology, music and Oriental studies.

SHEFFIELD.-The following appointments have recently been made: $\mathbf{R}$. W. John, to be research assistant to the Department of Pathology ; Douglas Harrison, to be assistant lecturer in electrical engineering; Donald Havenhand, to be assistant lecturer in metallurgy.

\section{Science News a Century Ago}

\section{An Ascent of the Peak of Demawund}

Ar a meeting of the Royal Geographical Society held on January 8, 1838, extracts were read from three communications. One of these was an account of an ascent of the peak of Demawund in September 1837 by Taylor Thomson, the paper being presented by W. F. Ainsworth (1807-96), who had been surgeon and geologist to the Euphrates expedition of Colonel Chesney. The mountain, it was stated, was about 40 miles east-north-east of Teheran and previously there had been no account of its ascent by a European or any measurement of its height. Thomson left Teheran on September 4, and after obtaining guides at a village, ascended to the summit on September 9 and spent the night there in a cave which was heated to upwards of $76^{\circ} \mathrm{F}$. by the sulphurous vapour which issued from the rocks. The geological formation of the mountain, from Gernah upwards for about 1,000 feet seemed, said Thomson, to be a bed of sandstone of the coal formation, with one seam of coal ; above this limestone occurred with a thickness of about 1,200 feet, then came greenstone coloured with iron to within $100 \mathrm{ft}$. of the summit, which was a deposit of pure sulphur. "The geological results of this expedition," said Ainsworth, "possess great interest by establishing the existence of a pseudo-volcano in these central districts of Western Asia, and ally themselves with the observations which Baron Humboldt has made upon the evidences of volcanic action, which he has traced everywhere on the great continent of Asia. It is a remarkable fact that throughout those districts of Taurus, Amanus, Kúrdistán and the Persian Apennines, in which I have travelled, I have never yet met with rocks of the secondary series. The absence of every member between the chalk and the primary formations is one of the most remarkable features in the geology of Western Asia."

\section{Fossil Discoveries in France}

ON January 13, 1838, the Athenceum again directed attention to the recent discoveries of fossils in a French mine, remarking that "Further inspection increases the importance of the discoveries of $\mathbf{M}$. Lartet and others . . . and fresh arrivals from him at the Academy of Sciences in Paris, produce new wonders. They combine the remains of animals, which, in all probability, no longer exist in nature, with some which do not appear to differ from those actually in being: the mine is still far from being exhausted, and a more favourable opportunity for the observations of geologists never before presented itself. The bones of the rhinoceros most abound; after these come those of deer, with their horns, and if an estimation may be formed by their size, the remains of a small and elegant species of ass or horse must have been deposited. New fragments of macrotherium gigans have come to light, which show that its claws bore a strong analogy to those of the Orycteropus. The bears must have been totally differ. ent from any yet discovered; and those bones which belong to an animal called Amphicyon, by M. Lartet, show a strong analogy between it and the dog".

\section{Samuel Woodward, I790-r838}

ON January 14, 1838, Samuel Woodward, the Norwich geologist and antiquary, died at the age of forty-seven years. Born in Norwich on October 2, 